\title{
Therapeutic Efficacy of Ethanolic Extract of Curcuma longa and its Component, Curcumin against Experimental Cryptosporidiosis in Mice
}

Alveena Ganai, Anish Yadav, Rajesh Katoch, Dibyendu Chakraborty, Pawan Kumar Verma, Meenu Katoch ${ }^{1}$, Amit Kumar ${ }^{1}$

10.18805/IJAR.B-4708

\begin{abstract}
Background: Cryptosporidiosis caused by Cryptosporidium spp. is a zoonotic disease and is the most prevalent pathogens worldwide and leads to severe diarrhoeal diseases and affects the immunological status of the individual. Thus, the study was undertaken to examine the anti-cryptosporidial efficacy of curcumin in comparison with ethanolic extract of curcuma longa in immunocompromised mice infected with oocysts isolated from cattle calves of Jammu region and identified as Cryptosporidium parvum using nested PCR on small subunit ribosomal ribonucleic acid (SSU rRNA) gene.

Methods: Two hundred female Swiss albino mice were equally divided into ten groups. Group I were kept as a healthy control, group II were immunocompromised, group III were immunocompromised and infected, group IV animals were immunocompromised, infected and treated orally with nitazoxanide. Animals in groups V to VII were immunocompromised, infected and treated with ethanolic extract of $C$. longa @ 4, 6 and $8 \mathrm{mg} / \mathrm{kg} /$ day/os respectively whereas groups VIII to X were immunocompromised, infected and treated with pure salt of curcumin @ 4,6 and $8 \mathrm{mg} / \mathrm{kg} /$ day/os respectively for 5 successive days. Thus, mean oocysts per gram faeces, body weight gain and histopathological changes were measured in different groups.

Result: Administration of curcumin as a therapeutic agent @ $8 \mathrm{mg} / \mathrm{kg}$ body weight for five days resulted in higher percent mean oocyst reduction of $74.03 \%$ and improved body weight gain in experimentally infected mice. Histopathological changes showed that treatment with oral curcumin (group $\mathrm{X}$ ) in animals had minimal and improved intestinal lesions as compared to animals treated with $C$. longa (group VII). Altogether, curcumin showed promising anticryptosporidial effects under in vivo conditions and deserves further exploration.
\end{abstract}

Key words: Curcumin, Cryptosporidiosis, Curcuma longa, Mice, Nitazoxanide, Zoonotic.

\section{INTRODUCTION}

Cryptosporidium parvum is a well recognized cause of diarrhoea in immunologically healthy and immuno compromised humans and animals throughout the world (Fayer,1986) and India (Brar et al. 2017) including recent prevalence reported in Jammu region (Yadav, 2012). Cryptosporidiosis is characterized by acute gastrointestinal disturbances, mucoid or hemorrhagic watery diarrhoea, fever, lethargy, anorexia and loss of body condition leading to significant economic losses in farm animals (Navin and Juranek, 1984). It is a potent food and drinking water contaminant which severely affects superficial epithelial cells throughout the entire gastrointestinal tract but can also be rarely found in airways, pancreatic ducts and biliary ducts (Laurent et al. 1999). Immunocompromised mice served as an excellent model to study experimental $C$. parvum infection (Ndao et al. 2013). Also, there is a recent report from Jammu region on $C$. parvum infection causing severe enteric disease in immunocompromised wister rats (Sood et al. 2019).

A major problem concerning $C$. parvum is the lack of effective means for controlling infection. Many studies have been tested against cryptosporidiosis but drugs of herbal origin cause have been found to cause minimal side effects and therefore newer effective alternatives must be explored to anticryptosporidial treatment (Roth et al. 1998).
Division of Veterinary Pharmacology and Toxicology, Faculty of Veterinary Sciences and Animal Husbandry, Sher-e-Kashmir University of Agricultural Sciences and Technology of Jammu, R.S Pura-181 102, Jammu and Kashmir, India.

${ }^{1}$ Division of Instrumentation, CSIR- Indian Institute of Integrative Medicine, Canal Road, Jammu-180 001, Jammu and Kashmir, India.

Corresponding Author: Alveena Ganai, Division of Veterinary Pharmacology and Toxicology, Faculty of Veterinary Sciences and Animal Husbandry, Sher-e-Kashmir University of Agricultural Sciences and Technology of Jammu, R.S Pura-181 102, Jammu and Kashmir, India. Email: aganai@rocketmail.com

How to cite this article: Ganai, A., Yadav, A., Katoch, R., Chakraborty, D., Verma, P.K., Katoch, M., Kumar, A. (2021). Therapeutic Efficacy of Ethanolic Extract of Curcuma longa and its Component, Curcumin against Experimental Cryptosporidiosis in Mice. Indian Journal of Animal Research. DOI: 10.18805/IJAR.B-4708.

Submitted: 06-07-2021 Accepted: 05-11-2021 Online: 22-12-2021

C. longa commonly known as turmeric, has been shown to possess anti-inflammatory, antiproliferative and potent antioxidant properties. Curcumin is a yellow natural polyphenolic compound extracted from turmeric root (C. longa). The active compound of curcumin is diferuloylmethane $[1,7$ bis-(4-hydroxy-3-methoxyphenyl) hepta-1,6-diene-3,5- 
Therapeutic Efficacy of Ethanolic Extract of Curcuma longa and its Component, Curcumin against Experimental......

dione], which is mainly responsible for the pharmacological effects (Shahiduzzaman and Daugschies, 2011). Antiprotozoal activities of curcumin have been described for Plasmodium falciparum (Cui et al. 2007), Leishmania spp. (Koide et al. 2002) and Trypanosoma spp. (Nose et al. 1998). Many other studies have highlighted anti-cryptosporidail activity of curcumin (Khalafalla et al. 2011 and CervantesValencia et al. 2016). Therefore, the aim of the present study was to evaluate the activity of ethanolic extract of $C$. longa and curcumin against $C$. parvum oocysts isolated from the faeces of cattle calves of Jammu region in Swiss albino mice.

\section{MATERIALS AND METHODS Collection and purification of parasite}

The experiment was conducted in summer, monsoon, premonsoon and winter seasons of Jammu region from the starting session of January 2018 till the end of December 2018. Cryptosporidium oocysts were collected from an eighteen day old cow calf suffering from clinical cryptosporidiosis, in an organized cattle farm of Jammu region. Further, the experiments were carried out in the department of veterinary parasitology, Sher-e-Kashmir University of Agricultural Sciences and Technology, R.S Pura, Jammu. Infection was confirmed by modified Ziehl Neelsen staining technique (Henricksen and Pohlenz, 1981). Confirmation of $C$. parvum was done through amplification of gp 60 gene using a nested PCR (Alves et al. 2003). Oocysts were purified from the faeces by primary and secondary purification methods. Primary purification of the oocysts from faeces was done by modified Sheather's sucrose floatation techniques (Current et al. 1983) and secondary purification of the oocysts was done by a discontinuous step-gradient centrifugation technique (Arrowood and Sterling, 1987). The final concentration of purified $C$. parvum oocysts was adjusted to $10^{8} / \mathrm{ml}$ using a Neubauer Chamber. It was fortified with streptopenicillin (streptomycin @ $100 \mu \mathrm{g} / \mathrm{ml}$ and penicillin @ $100 \mathrm{lU} / \mathrm{ml}$ ) and was stored at $4{ }^{\circ} \mathrm{C}$ for further use.

\section{Preparation of ethanolic extract of $C$. longa}

C. longa tuber was purchased from the local market, completely dried, powdered and then ethanolic extract was prepared. Ethanolic extract of $C$. longa was prepared as per the method of Harborne (1998). The per cent extractability of ethanolic extract was determined as per the formula,

$\%$ Extractability $=\frac{\text { Weight of the extract obtained }}{\begin{array}{c}\text { Weight of plant material }(\text { powder }) \\ \text { taken for extraction }\end{array}} \times 100$

Different working concentrations of $C$. longa extract were prepared in HPLC grade methanol and stored in a refrigerator at $4^{\circ} \mathrm{C}$.

Preparation of the stock solutions and calibration of standard compound curcumin stock solution of the pure reference compound, curcumin (sigma-Aldrich, USA) @ 1.0 $\mathrm{mg} / \mathrm{ml}$ was prepared in HPLC grade methanol and stored in a refrigerator at $4^{\circ} \mathrm{C}$. From the stock solution, working solutions for each reference compound were prepared by dilution with HPLC grade methanol. Two microliters of each dilution was injected for the preparation of a calibration curve.

\section{HPLC analysis}

Curcumin was separated and quantified by a Shimadzu HPLC system (Kyoto, Japan) consisting of an LC-10 ATvp pump, SIL-10 ADvp automatic sampling unit (auto sampler), CTO-10 and SCL-10 Avp as the system controller. Class VP software (version 6.10) (Company, City and Country) was used for data analysis and data processing. The samples were analyzed at $30^{\circ} \mathrm{C}$ on RP-18.5 $\mu \mathrm{m}, 250 \times 4$ $\mathrm{mm}$ i.d. Merck (Darmstadt, Germany) column. Photo Diode Array (PDA) detection was performed at $423 \mathrm{~nm}$. The analysis was carried out using a mobile phase of methanol: water (2:3) which was delivered at a flow rate of $0.7 \mathrm{ml} / \mathrm{min}$.

\section{The animals}

The study was conducted on 200 female Swiss albino mice. These mice aged two weeks, were procured from Indian Institute of Integrative Medicine (IIIM), Jammu. Mice were maintained in separate cages, provided with pelleted food, water adlibitum and were initially acclimatized for one week. Prepatent and patent periods were observed and mean oocysts shedding were calculated. They were all free from any parasitic infection on three consecutive days, as determined by examining their stools using a formol-ether concentration method and modified Ziehl-Neelsen technique (Henricksen and Pohlenz, 1981).

\section{Immunosuppression and infection}

Immunosuppression in groups II to $X$ animals was carried at age of 3 weeks (seven days prior to the inoculation of the infection) by administering dexamethasone @ $30 \mu \mathrm{g} / \mathrm{ml}$ in drinking water and continued till the end of the experiment. Mice of groups III to $X$ were infected orally with $10^{4}$ oocysts/ animal (Tarazona, 1998) at 4 weeks of age.

\section{Experimental design}

All the female Swiss albino mice were randomly divided into ten groups i.e., group I to group X, with 20 animals each which were housed in separate cages. Group I mice served as healthy control and received distilled water. Group II mice served as control for immunocompromised and were administered dexamethasone @ $30 \mu \mathrm{g} / \mathrm{ml}$ in drinking water. Group III mice were given dexamethasone and also were given C. parvum oocysts @ 104 oocysts/animal (Tarazona et al. 1998) orally. Group IV animals were immunocompromised, infected and treated orally with nitazoxanide @ 150 mg/kg/ day (Blagburn, 1998). Group V, VI and VII animals were immunocompromised, infected and treated with ethanolic extract of $C$. longa @ 4, 6 and $8 \mathrm{mg} / \mathrm{kg} /$ day/os, respectively. Group VIII, IX and X animals were immunocompromised, infected and treated orally with pure salt of curcumin (SigmaAldrich, USA) and given @ 4, 6 and 8 mg/kg/day/os, respectively. In the present study, initial dose ( $4 \mathrm{mg} / \mathrm{kg} /$ day $/ \mathrm{os}$ ) of curcumin was used as per the findings of Cervantes-Valencia et al. 
(2016) against Eimeria spp. (coccidian protozoa). Treatment with all the therapeutic drugs was started simultaneously at $5^{\text {th }}$ DPI and continued for 5 successive days i.e. upto $11^{\text {th }}$ DPI. Eight mice were euthanized humanly using ether inhalation on $7^{\text {th }} \mathrm{DPI}$ and the remaining 12 mice were sacrificed on $11^{\text {th }}$ DPI.

\section{Parameters for therapeutic evaluation}

Therapeutic evaluation of ethanolic extract of $C$. longa and curcumin against experimental cryptosporidiosis in mice was assessed based on oocysts per gram of faeces voided, average body weight of the animals and pathological alterations recorded in necropsy animals. In order to monitor oocysts count throughout the experiment, pooled faecal sample of the animals of each group were collected. Initially the oocysts count was measured on day of treatment $(0$ DPT) followed by $3^{\text {rd }}, 5^{\text {th }}$ and $7^{\text {th }}$ DPT. Per cent efficacy was monitored on $7^{\text {th }}$ day post treatment.

The number of oocysts per gram of faeces was calculated using the method of Grinberg et al. (2002). The percent mean oocysts reduction was calculated as per the formula,

$$
\begin{aligned}
& \% \text { Mean oocysts reduction }= \\
& \frac{\text { Mean OPG (0 day) - Mean OPG (Post treatment) }}{\text { Mean OPG (0 day) }} \times 100
\end{aligned}
$$

Average body weight of the experimental animals was recorded on $0,5,7,9$ and $11 \mathrm{DPI}$.

Statistical analysis of data was done using a two way ANOVA (Snedecor and Cocharan, 1994) and the means having significant difference were ranked as per Duncan's multiple range test (Duncan, 1955).

Further, for histopathological observations, intestines were collected in $10 \%$ neutral buffered formalin. Paraffin blocks were prepared, 4-6 $\mu$ sections were cut and stained with haematoxylin and eosin stain (Luna, 1968).

\section{Ethical aspects}

The institutional animal Ethical Committee of Sher-eKashmir University of Agricultural Sciences and Technology, Jammu granted an approval for the conduct of present work vide letter number-3/IAEC-17/2017.

\section{RESULTS AND DISCUSSION}

Results of nested PCR are shown in Fig 1 where amplification of gp60 gene yielded a clear band of $850 \mathrm{bp}$, confirming the presence of $C$. parvum in faecal samples of cattle calves suspected to be suffering from cryptosporidiosis.

Extractability percent of ethanolic extract of $C$. longa was recorded to be $6.4 \%$. HPLC PDA chromatogram at $423 \mathrm{~nm}$ showed peak of curcumin in a standard marker preparation and in the $C$. longa extract sample. Resolution of curcumin was clear and made their quantification easier. Analysis revealed that the concentration of curcumin in extract was $1.6 \mu \mathrm{g} / \mu \mathrm{L}$ and showed characteristic retention time of curcumin (13.192 min) as shown in Fig 2. Curcumin was considered as the major chemical, constituting $25 \%$ of the extract.

The results of the present study showed that $C$. parvum shedding in the mice started at $5^{\text {th }} \mathrm{DPI}$ and at $7^{\text {th }} \mathrm{DPI}$ the mean OPG was at its peak $(8916 \pm 139)$ in infected control animals (Group III) with \% mean oocysts increase of $33.75 \%$. The mean OPG progressively decreased to $4216 \pm 981$ at $11^{\text {th }}$ DPI with \% mean oocysts reduction of $36.75 \%$ (Table 1 ). In group IV animals, the mean OPG count at $11^{\text {th }}$ DPI was the lowest $(750 \pm 111.803)$ among all infected groups and maximum percent of oocysts reduction (88.88\%) was also

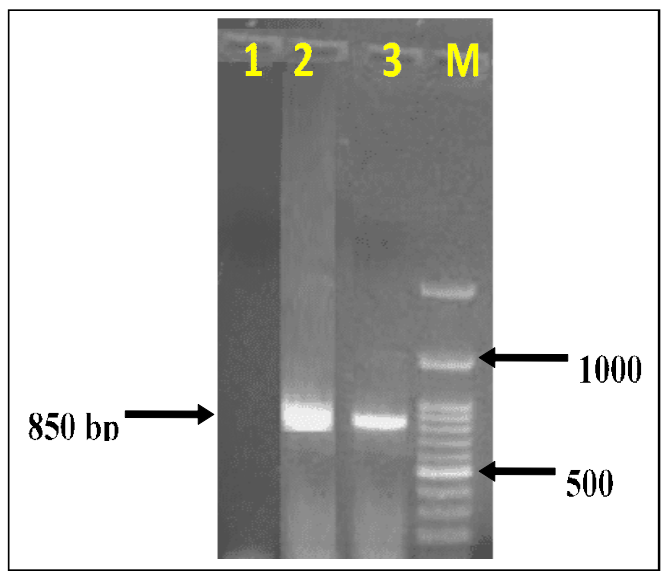

Fig 1: Amplification of $C$. parvum by Nested PCR of gp60 PCR. M-100 bp DNA ladder. Lane 1- Negative control, Lane 2 Positive control, Lane 3-Test sample.

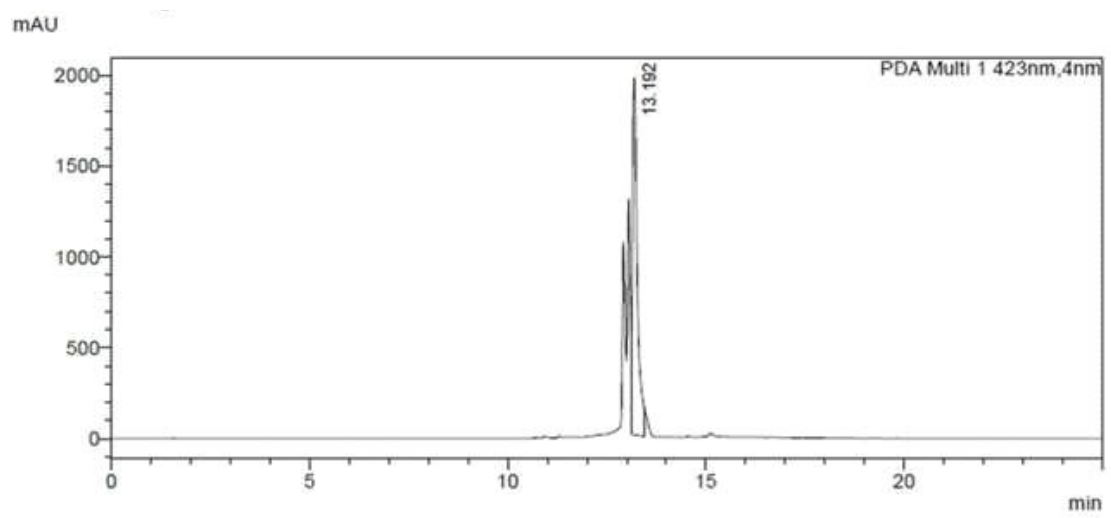

Fig 2: Chromatogram showing the peak of curcumin present in ethanolic extract of Curcuma longa. 
seen in this group. This is in accordance with Blagburn et al. (1998) who also used $150 \mathrm{mg} / \mathrm{kg}$ and found it to be most effective in reducing oocysts shedding. The treatment with pure salt of curcumin on $11^{\text {th }}$ DPI in group $X$ resulted in significantly lower mean oocysts count $(1666 \pm 307.318)$ and a higher percent mean oocysts reduction $(74.03 \%)$ as compared to group VII in which mean oocysts count was $2416.67 \pm 436.208$ and mean oocysts reduction was $62.83 \%$. All doses of curcumin gave significantly higher mean oocysts reduction as compared to different formulations of ethanolic extract of $C$. longa containing equivalent concentration of curcumin on $11^{\text {th }} \mathrm{DPI}$. Anti-coccidial efficacy of curcumin has been reported by Cervantes-Valencia et al. (2016) which correlates with our findings.

Our study showed significant decrease in average body weight of mice in group III animals $(18.81 \pm 0.959)$ as compared to group I animals $(22.51 \pm 0.688)$ on $7^{\text {th }} \mathrm{DPI}$. Present observations are in agreement with the findings of Castro et al. (2012) and Mirza-Qavamiand Sadraei (2011) who have also reported weight loss because of cryptosporidiosis in mice. Also, on $7^{\text {th }} \mathrm{DPI}$, the average body weight was higher in groups of mice that received therapeutic treatment including ethanolic extract of $C$. longa and curcumin when compared to group III even though this difference was non-significant. Moreover, the animals treated with synthetic curcumin in group $X$ showed higher body weight $(23.915 \pm 2.224)$ when compared with those administered same dose of $C$. longa in group VII (23.01 \pm 2.057) on $11^{\text {th }}$ DPI (Fig 3).
The present study showed the peak oocysts intensity on $7^{\text {th }}$ DPI but, Mirza-Qavami and Sadraei (2011) reported peak severity occurred on $9^{\text {th }} \mathrm{DPI}$ and then infection gradually subsided on $12^{\text {th }}$ DPI and cleared by $16^{\text {th }}$ DPI, whereas Verdon et al. (1998) observed that infection cleared off completely between $14^{\text {th }}$ and $21^{\text {st }} \mathrm{DPI}$. No gross or microscopic abnormalities were seen in gastrointestinal tract of group I and II animals. In group III animals, intestinal sections showed severe enteritis with stunted and fused villi and severe infiltration of inflammatory cells were seen in lamina propria and submucosa (Fig 4a). Numerous oocysts were also seen attached to the superficial epithelium of enterocytes. Similar pathological lesions in the intestines as found in the group III animals in the present study have also been observed by other workers (Castro et al. 2012). Overall, animals in groups given anticryptosporidial therapy showed only mild inflammation of lamina propria and no oocysts were seen attached to the villi on $7^{\text {th }}$ DPI. Even though, effects of treatment were best in group IV in terms of minimal inflammation in GIT, group $X$ animals also had markedly reduced degree of inflammation and histological sections appeared nearly comparable to those of animals in group IV (Fig 4b). Furthermore, lesions were less severe in groups given curcumin as compared to those given ethanolic extract of $C$. longa.

The present study demonstrated the use of curcumin @ $8 \mathrm{mg} / \mathrm{kg}$ body weight provided maximum reduction in oocysts excretion, helped in maintaining body weight of animals and reduced severity of intestinal lesions as

Table 1: Cryptosporidium spp. mean oocysts count and percent mean alteration in mice of different groups at different intervals.

\begin{tabular}{|c|c|c|c|c|}
\hline \multirow[b]{2}{*}{ Groups } & \multicolumn{4}{|c|}{ Period } \\
\hline & $5^{\text {th }}$ DPI $(0$ DPT $)$ & $7^{\text {th }} \mathrm{DPI}(3 \mathrm{DPT})$ & $9^{\text {th }} \mathrm{DPI}(5 \mathrm{DPT})$ & $11^{\text {th }} \mathrm{DPI}(7 \mathrm{DPT})$ \\
\hline Group I & $0.000 \pm 0.000^{\mathrm{A}}$ & $0.000 \pm 0.000^{A}$ & $0.000 \pm 0.000^{\mathrm{A}}$ & $0.000 \pm 0.000^{\mathrm{A}}$ \\
\hline Group II & $0.000 \pm 0.000^{\mathrm{A}}$ & $0.000 \pm 0.000^{\mathrm{A}}$ & $0.000 \pm 0.000^{A}$ & $0.000 \pm 0.000^{\mathrm{A}}$ \\
\hline Group III & $6666.67 \pm 1370.320^{\mathrm{B}, \mathrm{a}, \mathrm{b}}$ & $\begin{array}{c}8916.67 \pm 1398.908^{\mathrm{C}, \mathrm{b}} \\
(33.75 \%)\end{array}$ & $\begin{array}{c}6333.34 \pm 1229.273^{\mathrm{c}, \mathrm{a}, \mathrm{b}} \\
(4.99 \%)\end{array}$ & $\begin{array}{c}4216.7 \pm 981.63^{\mathrm{D}, \mathrm{a}} \\
(36.75 \%)\end{array}$ \\
\hline Group IV & $6750 \pm 1022.660^{\mathrm{B}, \mathrm{C}}$ & $\begin{array}{c}4083.34 \pm 888.976^{\mathrm{B}, \mathrm{b}} \\
(39.51 \%)\end{array}$ & $\begin{array}{c}2166.67 \pm 380.058^{\mathrm{B}, \mathrm{a}, \mathrm{b}} \\
(67.91 \%)\end{array}$ & $\begin{array}{c}750 \pm 111.803^{\mathrm{B}, \mathrm{a}} \\
(88.88 \%)\end{array}$ \\
\hline Group V & $6736 \pm 1487.447^{\mathrm{B}}$ & $\begin{array}{c}6000 \pm 1310.216^{\mathrm{B}} \\
(11.11 \%)\end{array}$ & $\begin{array}{c}5016.67 \pm 1331.770^{\mathrm{C}} \\
(25.68 \%)\end{array}$ & $\begin{array}{c}3250 \pm 727.438^{\mathrm{D}} \\
(51.85 \%)\end{array}$ \\
\hline Group VI & $6333.34 \pm 1842.402^{\mathrm{B}}$ & $\begin{array}{c}5166.67 \pm 1301.708^{\mathrm{B}} \\
(18.42 \%)\end{array}$ & $\begin{array}{c}3866.67 \pm 1106.546^{\mathrm{B}, \mathrm{C}} \\
(38.95 \%)\end{array}$ & $\begin{array}{c}2533.34 \pm 338.296^{\mathrm{C}, \mathrm{D}} \\
(60 \%)\end{array}$ \\
\hline Group VII & $6500 \pm 1543.805^{\mathrm{B}, \mathrm{b}}$ & $\begin{array}{c}4666.67 \pm 401.386^{\mathrm{B}, \mathrm{a}, \mathrm{b}} \\
(28.21 \%)\end{array}$ & $\begin{array}{c}3750 \pm 381.881^{\mathrm{B}, \mathrm{a}} \\
(42.30 \%)\end{array}$ & $\begin{array}{c}2416.67 \pm 436.208^{\mathrm{C}, \mathrm{D}, \mathrm{a}} \\
(62.83 \%)\end{array}$ \\
\hline Group VIII & $6916.67 \pm 1135.904^{\mathrm{B}, \mathrm{b}}$ & $\begin{array}{c}5166.67 \pm 691.215^{\mathrm{B}, \mathrm{a}, \mathrm{b}} \\
(25.30 \%)\end{array}$ & $\begin{array}{c}4666.67 \pm 833.333^{\mathrm{B}, \mathrm{C}, \mathrm{a}, \mathrm{b}} \\
(32.53 \%)\end{array}$ & $\begin{array}{c}2916.67 \pm 554.026^{\mathrm{C}, \mathrm{D}, \mathrm{a}} \\
(57.83 \%)\end{array}$ \\
\hline Group IX & $6540 \pm 1147.461^{\mathrm{B}, \mathrm{c}}$ & $\begin{array}{c}4666.67 \pm 586.894^{\mathrm{B}, \mathrm{b}, \mathrm{c}} \\
(28.21 \%)\end{array}$ & $\begin{array}{c}3500 \pm 258.199^{\mathrm{B}, \mathrm{a}, \mathrm{b}} \\
(46.15 \%)\end{array}$ & $\begin{array}{c}2000 \pm 223.607^{\mathrm{B}, \mathrm{C}, \mathrm{D}, \mathrm{a}} \\
(69.23 \%)\end{array}$ \\
\hline Group X & $6416.67 \pm 723.610^{\mathrm{B}, \mathrm{c}}$ & $\begin{array}{c}4166 \pm 781.736^{\mathrm{B}, \mathrm{b}} \\
(35.06 \%)\end{array}$ & $\begin{array}{c}3083 \pm 597.448^{\mathrm{B}, \mathrm{a}, \mathrm{b}} \\
(51.94 \%)\end{array}$ & $\begin{array}{c}1666 \pm 307.318^{\mathrm{B}, \mathrm{C}, \mathrm{a}} \\
(74.03 \%)\end{array}$ \\
\hline
\end{tabular}

${ }^{a b c}$ Means bearing different superscripts within a row differ significantly and A,B,C Means bearing different superscripts within the column differ significantly.

Where, DPI- Days post infection and DPT- Days post treatment.

Values in parenthesis indicate \% reduction in mean oocysts count in comparison to day 0 of the group. 


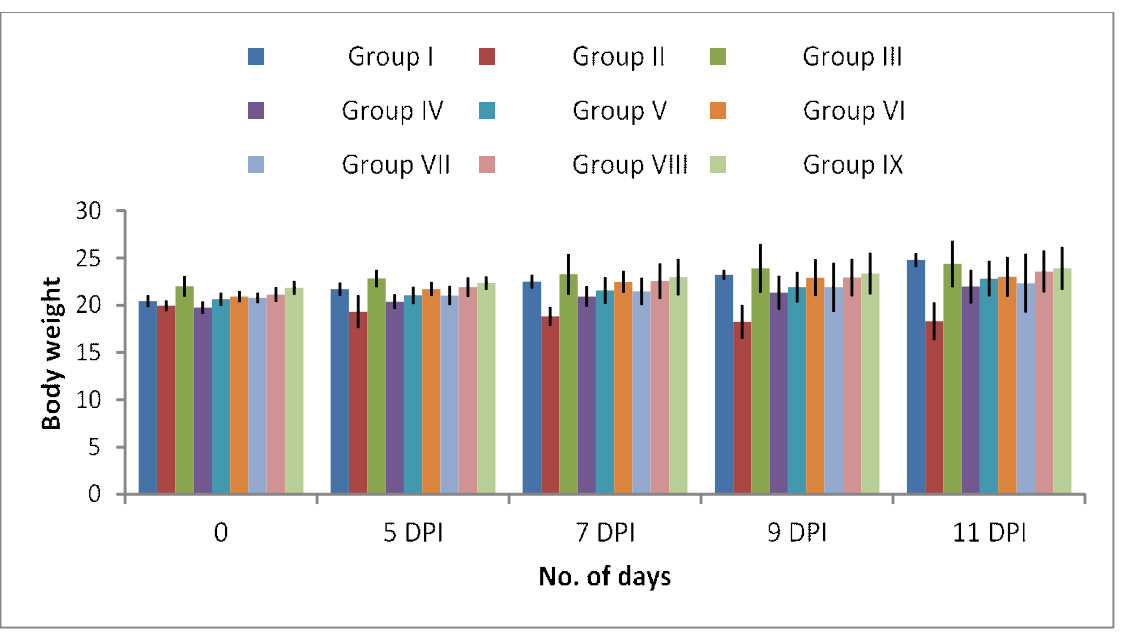

Fig 3: Average body weight (gms) of mice in control and different treatment groups at $0,5^{\text {th }}, 7^{\text {th }}, 9^{\text {th }}$ and $11^{\text {th }}$ day PI.

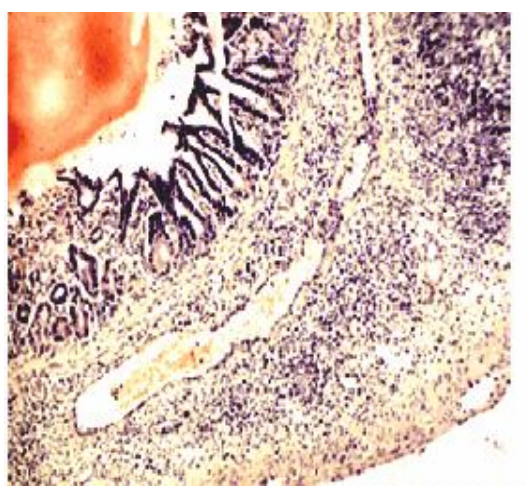

(a)

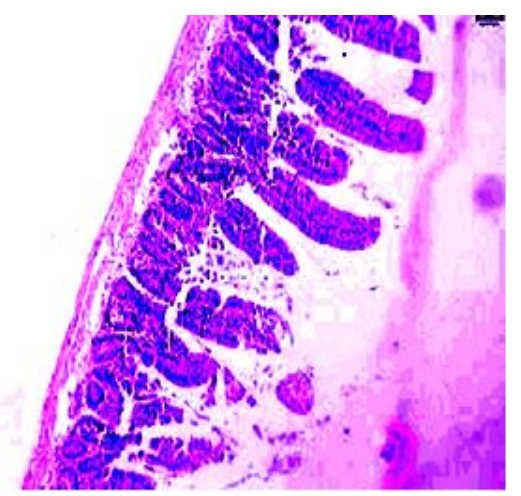

(b)

Fig 4: Histopathological alterations in intestinal tissues of infected group. (a) Severe thickening of the wall of intestine and infiltrated by inflammatory cells $(H \& E \times 100)$ and (b) A minimal inflammation of lamina propria $(H \& E \times 100)$.

compared to ethanolic extract of $C$. longa. This could probably due to the presence of other constituents in ethanolic extract of $C$. longa and therefore interactions among various constituents may be the cause of reduced efficacy of ethanolic extract of $C$. longa as compared to pure salt of curcumin. Further studies can be carried out to evaluate the ethanolic extract of $C$. longa and curcumin which would be beneficial in the treatment and control of cryptosporidiosis in other animal species and humans.

\section{ACKNOWLEDGEMENT}

The authors are grateful to Sher-e-Kashmir University of Agricultural Sciences and Technology, Jammu, India for the encouragement.

\section{Conflict of interest}

The authors declare that they have no conflict of interest.

\section{REFERENCES}

Arrowood, M.J. and Sterling, C.R. (1987). Isolation of Cryptosporidium oocysts and sporozoites using discontinuous sucrose and isopycnic percoll gradients. Journal of Parasitology. 78: 314-319.
Alves, M., Xiao, L., Sulaiman, I., Lal, A.A., Matos, O. and Antunes, F. (2003). Subgenotype analysis of Cryptosporidium isolates from humans, cattle and zoo ruminants in Portugal. Journal of Clinical Microbiology. 41: 2744-2747.

Blagburn, B., Drain, K., Land, T.M., Kinard, R.G., Moore, P.H., Lindsay, D.S., Patrick, D.A., Boykin, D.W and Tidwell, R.R. (1998). Comparative efficacy evaluation of dicationic carbazole compounds, nitazoxanide and paromomycin against Cryptosporidium parvum infections in a neonatal mouse model. Antimicrobial and Chemotherapy Journal. 00664804/98/\$04.0010. 2877-2882.

Brar, A.P.S., Sood, N.K., Kaur, P., Singla, L.D., Sandhu, B.S., Gupta, K., Narang, D., Singh, C.K and Chandra, M. (2017). Periurban outbreaks of bovine calf scours in Northern India caused by Cryptosporidium in association with other enteropathogens. Epidemiology and Infection. 145: 27172726.

Castro, I.C., Oliveira, B.B., Slowikowski, J.J., Coutinho, B.P., Siqueira, F.J.W.S., Costa, L.B., Sevilleja, J.E., Almeida, C.A., Lima, A.A.M., Warren, C.A., Oriá, R.B. and Guerrant, R.L. (2012). Arginine reduces Cryptosporidium parvum infection undernourished suckling mice involving both nitric oxide synthase and arginase. Nutrition. 28: 678-685. 
Cervantes-Valencia, M.E., Alcalá-Canto, Y., Sumano-Lopez, H., Ducoing-Watty, A.M and Gutierrez-Olvera, L. (2016). Effects of Curcuma longa dietary inclusion against Eimeria spp. in naturally-infected lambs. Small Ruminant Research. 136: 27-35.

Cui, L., Miao, J and Cui, L. (2007). Cytotoxic effect of curcumin on malaria parasite Plasmodium falciparum: Inhibition of histone acetylation and generation of reactive oxygen species. Antimicrobial and Chemotherapy. 51: 488-494.

Current, W.L., Reese, N.C., Ernst, J.V., Bailey, W.S., Heyman, M.B. and Weinstein, W.M. (1983). Human cryptosporidiosis in immunocompetent and immunodeficient persons. Studies on outbreak and experimental transmission. New England Journal of Medicine. 308: 1252-1258.

Duncan, B.B. (1955). Multiple range and multiple ' $F$ ' test: Biometrics. 11: 1-42.

Fayer, R. and Ungar, B.L.P. (1986). Cryptosporidium spp. and cryptosporidiosis. Microbiology Review. 50: 458.

Grinberg, A., Lopez-Villalobos, N., Markovics, A., Kosak, A., Galindez, J. and Tranquillo, V. M. (2002). Controlling the onset of natural cryptosporidiosis in calves with paromomycin sulphate. Veterinary Record. 151: 606-608.

Harborne. (1998). Chapman and Hall London. 1: 135-137.

Henricksen, S.A. and Pohlenz, J.F.L. (1981). Staining of cryptosporidia by a modified Ziehl-Neelsen technique. Acta Veterinaria Scandinavica. 22: 594.

Koide, T., Nose, M., Ogihara, Y., Yabu, Y. and Ohta, N. (2002). Leishmanicidal effect of curcumin in vitro. Biological and Pharmaceutical Bulletin. 25: 131-133.

Khalafalla, R.E., Müller, U., Shahiduzzaman, M., Dyachenko, V., Desouky, A.Y., Alber, G and Daugschies, A. (2011). Effects of curcumin (diferuloylmethane) on Eimeria tenella sporozoites in vitro. Parasitology Research. 108: 879-886.

Laurent, F., McCole, D., Eckmann, L. and Kagnoff, M.N. (1999). Pathogenesis of Cryptosporidium parvum infection. Microbes and Infection. 1: 141-148.

Luna, L.G. (1968). Histologic Staining Methods of the Armed Forces Institute of Pathology, (ed. $3^{\text {rd }}$ ), McGraw Hill Book Company, New York.
Mirza-Qavami, S.M and Sadraei, J. (2011). An examination of Cryptosporidium parvum infection in neonate BALB/C mice and rats. Jundishapur Journal of Microbiology. 4: 185-190.

Navin, T.R. and Juranek, D.D. (1984). Cryptosporidiosis: Clinical, epidemiologic and parasitologic review. Reviews of Infectious Diseases. 6: 313.

Ndao, M., Nath Chowdhury, M., Sajid, M., Marcus, V., Mashiyama, S.T. and Sakanari, J. (2013). A cysteine protease inhibitor rescues mice from a lethal Cryptosporidium parvum infection. Antimicrobial and Chemotherapy. 57: 6063-6073.

Nose, M., Koide, T., Ogihara, Y., Yabu, Y and Ohta, N. (1998). Trypanocidal effects of curcumin in vitro. Biological and Pharmacological Bulletin. 21: 643-645.

Roth, G., Chandra, A. and Nair, M. (1998). Novel bioactivities of Curcuma longa constituents. Journal of Natural Products. 61: 542-545.

Shahiduzzaman, M. and Daugschies, A. (2011). Curcumin: A natural Herb Extract with Antiparasitic Properties. Nature Helps. Springer. 141-152.

Snedecor, W.G. and Cochran, W.G. (1994). Statistical Methods. $8^{\text {th }}$ edn., lowa State University Press, Ames.

Sood, S., Yadav, A., Katoch, R., Bhagat, M., Sharma, A., Rahman, S., Verma, P., Rajat, Khursheed, A., Ganai, A and Sharma, S. (2019). Oxidative stress and clinico-pathological alterations induced by Cryptosporidium parvum infection in a rat model. Indian Journal of Animal Research. 53: 1431-1435.

Tarazona, R., Blewett, D.A. and Carmona, M.D. (1998). Cryptosporidium parvum infection in experimentally infected mice: Infection dynamics and effect of immunosuppression. Folia Parasitologica. 45: 101-107.

Verdon, R., Polianski, J., Grodet, A., Garry, L. and Carbon, C. (1998). Cryptosporidium parvum biliary tract infection in adult immunocompetent and immunosuppressed mice. Medical Microbiology. 47: 71-7.

Yadav, A., Katoch, R., Katoch, M., Aggarwal, R, Khajuria, J.K., Godara, R. and Kalha, R. (2012). Cross sectional study and analysis of potential risk factors for Cryptosporidium spp. infection in buffalo calves in Jammu. Veterinary Practioner. 13: 278-281. 